\title{
Attitudinal Determinants of Educational Resources Management for Enhancing Students' Performance in Secondary Schools in Bungoma County, Kenya
}

\author{
Dr. Moses Wesang'ula \\ Masinde Muliro University of Science and Technology
}

*Corresponding Author: Dr. Moses Wesang'ula, Masinde Muliro University of Science and Technology

\begin{abstract}
Education in a school is explored by provision of resources, their maximum utilization and management. Proper management of resources enhances students' performance and achieves the educational objectives. The purpose of this study was to examine the attitudinal determinants of educational resources management and their influence on students' performance in secondary schools in Bungoma County. A descriptive survey design was adopted. The study population composed of 112 head teachers, 1,120 teachers, 4,480 students and 9 County Quality Assurance and Standards Officers. Simple random sampling method, stratified sampling technique, saturated sampling technique and purposive sampling method were used to select samples. Questionnaires and in-depth interview guides, observation schedules and document analysis were used to collect data. Reliability of instruments was determined through a pilot study conducted in 3 secondary schools. Qualitative data from interviews was transcribed and reported according to emerging themes, categories and sub-categories while quantitative data was analyzed using descriptive statistics such as frequency counts, means and percentages. Pearson's product moment correlation coefficient was used to establish relationships between variables. Findings of the study revealed that there was a significant relationship between attitudinal determinants for educational resources management and students' performance in KCSE exams. From the study it is concluded that the attitude of teachers and students towards management and utilization of educational resources has influence on performance of students in KCSE exams. From the study, it is recommended that schools in the County should involve teachers in drafting the policies and regulations on management of educational resources for them to implement them without resistance.
\end{abstract}

Keywords: Students' performance, Attitudinal determinants, Management of educational resources, Psychological effects, Physiological effects

\section{LIST OF ACRONYMS}

BOM Boards of Management

CDF Constituency Development Fund

CEO County Education Officer

EFA Education for All

FAWE $\quad$ Forum for African Women Educationists

ICT Information and Communication Technology

IGAs Income Generating Activities

KCSE Kenya Certificate of Secondary Education

KFSSG Kenya Food Security Steering Group

MOE Ministry of Education

\section{INTRODUCTION}

The main aim of education is to bring about desirable change in behavior through acquisition of skills, attitudes, competencies, and imaginative thinking. Teaching is a complex and demanding task that requires highly specialized skills, knowledge and resources so as to influence student learning 
significantly (Mugure, 2012). Availability and utilization of resources in an organization is important in achievement of its goals and objectives. Students learning outcome is influenced by appropriate management of school resources. Investing in educational resources is the key to ensuring that schools become institutions where students work in unity, gain knowledge from each other and benefit from a supportive school environment, and consequently capitalize on student learning so that all students achieve their full learning potential (Mugure,2012)

Abayomi and Olukayode (2006) noted that student learning outcomes in schools is largely dependent on availability and appropriate management of educational resources, because students acquire relevant skills using these resources. The resources include physical facilities and material resources. These facilities play a pivotal role in the realization of the educational goals and objectives by fulfilling the physical and emotional needs of the staff and students (Abayomi \& Olukayode, 2006). Bausch and Ault (2008) define educational resources as materials that give help, support or aid to the teaching learning process. They therefore point out that education resources are materials or items which aid and support the teaching learning process in educational institutions.

Allwright (2000) noted that resources should teach students to learn, and that they should give teachers rationales for what they do. The success or failure of any organization, business or enterprise depends highly on the proper management of human and material resources. Effective management increases productivity. Ayeni (2005) points out that management would enhance the achievement of organizational goals with minimum cost if it is effective. He observes that the main causes of apparent failure of school system is lack of real or/and poor management. The resources for education are always scanty; the leaders are untrained while the policies that are poorly formulated are never implemented. No matter how good the teachers are and no matter how abundant the facility are provided and regardless of how well education is funded, not much was achieved unless there are good educational managers. Karim and Heckman (2005) noted that the learning industry is going through a transformation process through the use of innovative products and tools from the ICT revolution. However, they observed that it is important for the tools to be evaluated for appropriateness, effectiveness and usability from the point of view of the user, since this perceptive can assist teachers in choosing the best product and in managing the tools for optimum benefit.

Babette \& Reitzes (2011) remarked that integrating technology into teaching and learning is a slow and time-consuming process that requires considerable levels of support and encouragement for teachers. They say, besides this intrinsic resistance to change, it is alleged that schools also have a structure that prevents wide spread uses of resources, thus, the structure of the school hampers the power of new technologies for learning. They noted that introduction of computers requires significant changes in the curriculum, reallocation of resources, changes in teaching practices, and perhaps rearranging the fundamental structure of schools. The constant changing nature of technology makes it difficult for teachers to stay up to date with the latest technology, since everyday new software and hardware becomes available (Zhao, Pugh, Sheldon, \& Byers, 2002). Therefore, teachers, find it tricky and discouraging to keep chasing this elusive beast yet they are already struggling for time and energy. According to Becker (2007) technology is inherently unreliable and can break down at any time. He says, teachers who have less time in front of students, are unable spend the time troubleshooting problems that they may or may not be able to get solution. Therefore unless there is an urgent need for the use of technology and consistent support, teachers may choose not to use it in their teaching. Without continuous technical support, integration of technology in the classroom will never be adequately achieved (Babette \& Reitzes, 2011). Other aspects of teachers' conditions of working that are not directly related to technology, such as busy programmes, crowded school curricula and lack of support, have also been recognized as important factors affecting technology uses (Smerdon, Anderson, Iannotti, Cronen, Lanahan and Angeles, 2000)

Accurate statistical data of teaching resources are very important in the educational sector. Proper records of teaching resources (human and material) will help in effective management and achievement of educational objectives. Some administrators fail to provide accurate and reliable data on the number of staff, students enrolled and even materials available. This negatively impacts on effective management and utilization of teaching resources. Otu (2011) indicated that for teaching and learning resources to be effectively managed, teachers require well organized professional development programmes. This time for learning is especially important as schools integrate 
information and multimedia technologies into the classroom. When a school decides to install these technologies, each teacher must become adept at their use; identify suitable hardware and software for his or her subject content and students, and purpose to work using computer. Learning to use most current technologies well is accomplished best when teachers have time available to learn how to use them. Most teachers are unable to update their knowledge through exposure to conferences, workshops and seminars. Most schools are unable to organize such programmes for teachers. Teachers do not have access to current journals, textbooks and internet facilities. They, therefore, rely on their old textbooks, notes and materials. This lack of exposure on the part of the teacher affects his/her management and utilization of teaching materials. Zhao and Cziko (2001) observed that teachers' pedagogical values and their teaching practices are also factors that seem to influence their uses of technology. They pointed out that technology itself has also been mentioned as the source of a set of factors that influence its uses by teachers. Babette and Reitzes, (2011) noted that there are conflicting ideas about the worthiness of technology; therefore teachers are given conflicting advice on how technology should be used in schools. He observed that this puts teachers in a state of confusion about how valuable technology is in education; therefore, teachers end up rejecting technology completely and in fact most of them literally refuse to adopt it in their teaching practices.

There has been downward trend in performance in Kenya Certificate of Secondary Examination in Bungoma County (CEO's Office, 2014). The average mean scores were very low. This is an indicator that many schools performed dismally in KCSE exams. This poor performance has been attributed to inadequate number of teachers, inadequate syllabus coverage and high enrolment of students. However, the aspect on appropriate management of educational resources has not been considered with the magnitude it deserves yet it forms a basis for healthy learning. Academic performance of Bungoma County is below average and therefore it shows that poor management of educational resources may be influencing the academic performance of the students. This study therefore sought to establish the determinants of educational resources management for enhancing performance in secondary schools in Bungoma County.

\section{Methodology}

The current study was guided by Dale's cone of Experience (Dale, 1967), System Resource Theory on Organizational Effectiveness (Yutchman and Seashore, 1967) and reviewed literature. Dale (1967) in his cone of experience made a diagrammatic presentation that shows the importance of using resources in teaching. He classified the resources according to their effectiveness in communication at different levels. According to System Resource Theory on Organizational Effectiveness, effectiveness is an organization's ability to secure an advantageous bargaining position in its environment and to capitalize on that position to acquire, judiciously distribute, and monitor utilization of scarce resources. Yutchman and Seashore (1967) further view organizations such as schools as open systems which acquire inputs, engage in transformation process and generate outputs. This is supported by Bausch and Ault (2008) who equates a school to an industry which transforms given inputs into required outputs. Further, Oni (1995) cited by Akinsolu (2011) noted that the secondary school like any other organization receives inputs from its environment converts or processes the inputs and afterwards discharges output to the environment from where the input is increased. Yutchman and Seashore (1967) system resource theory of organizational effectiveness is relevant to this study because school interaction with its environment is critical for the acquisition of scarce educational resources which when utilized effectively should translate to good performance of students.

The current study was guided by Dale's cone of Experience (Dale, 1967), System Resource Theory on Organizational.The study adopted the descriptive survey research design. It was conducted in public secondary schools in Bungoma County. The study population included 112 heads teacher from 112 secondary schools in Bungoma county, 1,120 teachers, 4,480 form four Secondary School students and 9 Quality Assurance and Standards Officers .1344 Form IV students were sampled using stratified sampling method. 34 heads teacher were sampled by purposive sampling method while simple random sampling technique was used to select 336 teachers. Saturated sampling technique was used to sample 9 County Quality Assurance and Standards Officers (CQASOs. Data was gathered through questionnaires, in-depth interview guide, document analysis and observation schedules. The validity of instruments in the research was ensured by preparing items in the instruments that cover each of the study objectives and by seeking supervisors' opinions to asses content validity while test-retest 
method of establishing reliability was used to explore the reliability. The correlation co-efficient of responses were 0.86 and 0.84 for teachers' and students' questionnaires respectively. Quantitative data was analyzed using descriptive statistics such as frequency counts, percentages and means. Pearson's Product moment Correlation was used to establish the relationship between technological determinants of educational resources and students' performance in secondary schools. A likert type of scale was used to explore levels of influence by use of mean ratings.

\section{RESULTS AND DisCUSSION}

Teachers were involved in data collection based on the financial determinants of educational resources management and results tabulated as illustrated in table 2

Table2. Attitudinal determinants of management of Educational resources

\begin{tabular}{|c|c|c|c|c|c|c|c|c|c|c|c|c|c|}
\hline \multirow[t]{2}{*}{$\mathbf{S} / \mathbf{N}$} & \multirow[t]{2}{*}{ Statement } & \multicolumn{2}{|c|}{$\begin{array}{l}\text { Strongly } \\
\text { Agree }\end{array}$} & \multicolumn{2}{|c|}{ Agree } & \multicolumn{2}{|c|}{ Undecided } & \multicolumn{2}{|c|}{$\begin{array}{l}\text { Strongly } \\
\text { Disagree }\end{array}$} & \multicolumn{2}{|c|}{ Disagree } & \multicolumn{2}{|c|}{ Total } \\
\hline & & $\mathbf{f}$ & $\%$ & $\mathbf{f}$ & $\%$ & $\mathbf{f}$ & $\%$ & $\mathbf{f}$ & $\%$ & f & $\%$ & $\mathbf{f}$ & $\%$ \\
\hline 1. & $\begin{array}{l}\text { Teaching using educational } \\
\text { resources is time consuming }\end{array}$ & 73 & 22.9 & 152 & 47.8 & 0 & 0.0 & 24 & 7.5 & 69 & 21.7 & 318 & 100 \\
\hline 2. & $\begin{array}{c}\text { Teachers engage learners in } \\
\text { preparation of some } \\
\text { educational resources such as } \\
\text { charts. }\end{array}$ & 81 & 25.5 & 168 & 52.8 & 0 & 0.0 & 8 & 2.5 & 61 & 19.2 & 318 & 100 \\
\hline 3. & $\begin{array}{c}\text { Teachers fear using harmful } \\
\text { educational resources such as } \\
\text { realia like reptiles during } \\
\text { teaching. }\end{array}$ & 95 & 29.9 & 102 & 32.1 & 15 & 4.7 & 15 & 4.7 & 91 & 28.6 & 318 & 100 \\
\hline 4. & $\begin{array}{c}\text { Teachers ensure that } \\
\text { educational resources are } \\
\text { kept well. }\end{array}$ & 100 & 31.4 & 171 & 53.8 & 4 & 1.3 & 4 & 1.3 & 39 & 12.3 & 318 & 100 \\
\hline 5. & $\begin{array}{r}\text { Teachers repair educational } \\
\text { resources using their money. }\end{array}$ & 43 & 13.5 & 45 & 14.2 & 21 & 6.6 & 72 & 22.6 & 137 & 43.1 & 318 & 100 \\
\hline 6. & $\begin{array}{c}\text { Teachers purchase some } \\
\text { educational resources using } \\
\text { their own money. }\end{array}$ & 61 & 19.2 & 109 & 34.2 & 8 & 2.5 & 54 & 17.0 & 86 & 27.0 & 318 & 100 \\
\hline 7. & $\begin{array}{c}\text { Teachers adhere to guidelines } \\
\text { on control and use of } \\
\text { educational systems. }\end{array}$ & 73 & 22.9 & 205 & 64.5 & 4 & 1.3 & 10 & 3.1 & 26 & 8.2 & 318 & 100 \\
\hline 8. & $\begin{array}{c}\text { Teachers improvise and use } \\
\text { alternative educational } \\
\text { resources }\end{array}$ & 103 & 32.4 & 164 & 51.6 & 0 & 0.0 & 4 & 1.3 & 47 & 14.8 & 318 & 100 \\
\hline 9. & $\begin{array}{l}\text { Students participate in } \\
\text { preparation of some } \\
\text { educational resources }\end{array}$ & 63 & 19.8 & 138 & 43.4 & 8 & 2.5 & 15 & 4.7 & 94 & 29.6 & 318 & 100 \\
\hline
\end{tabular}

Table 2 illustrates that $70.7 \%$ of the respondents supported the fact that teaching using instructional resources was time consuming. Since their workload was too much for them, getting time to prepare the resources was not easy. An interview conducted with head teachers confirmed that it was time consuming. It was reported by $75.3 \%$ of respondents that teachers engaged students in preparation of some educational resources such as charts. They appreciated the willingness of students in supporting them. This reduces on expenses involved in sourcing for instructional resources. Money that could have been used to purchase for such resources would be channeled to other school activities. It was indicated by $63.2 \%$ of respondents that most students were willing to participate in preparation of these resources. Involving students in preparation of learning and teaching resources motivated students by boosting their interests, curiosity and eagerness to learn more. It was observed by $53.4 \%$ of the respondents that whenever teachers realized that they needed certain educational resources yet their school could not afford to procure them, they purchased them using their own money. This is because they knew the value of these educational resources and since they were results - oriented, they had to sacrifice their money. Additionally, $84 \%$ of the respondents reported that teachers improvised alternative educational resources whenever they realized that they could not afford to buy 
the right educational resources. Teachers were commended by $85.2 \%$ of the respondents for ensuring that educational resources were kept well while $27.7 \%$ of the respondents reported that whenever the educational resources got spoilt, teachers ensured that they were repaired. This suggests that teachers were prepared to ensure that students were taught using proper resources. The findings of the study also revealed that $62 \%$ of teachers were afraid of using certain educational resources such as electronics and even realia whether harmful or harmless during teaching. Their perceptions come out clearly that they fear being close to them, touching and even using them to demonstrate an item. The study indicates that $87.4 \%$ of teachers adhered to guidelines and policies set by the school to control the utilization of educational resources.

An interview with head teachers revealed that $60 \%$ of teachers felt that they were shortchanged during procurement of educational resources. This is due to the fact that they did not participate in purchasing of most of educational resources. Therefore whenever there was any breakdown of any facility, teachers did not bother. Sixty percent $(60 \%)$ of interviewed school head teachers said that some teachers could not use certain educational resources freely because they were never trained on how to use them. They wished that a course could be offered in teacher training institutions on how to operate educational media resources.

A Pearson Product Moment Correlation was run to test the hypothesis at an alpha level of 0.05 . The frequencies of responses on each and every item were established. The responses which were used included: teachers' attitude towards time consumption in using instructional resources; teachers' attitude towards engagement of students in preparation of instructional resources; teachers' attitude towards utilization of some educational resources such as realia and electronic media; teachers' attitude towards adherence to guidelines and policies set to control the utilization of educational resources; and teachers' attitude towards improvisation of alternative sources of educational resources. Their scores were run against the average mean scores of results obtained in KCSE exams in the years 2012, 2013 and 2014 for all schools under study. The results obtained were computed as shown in the table 3.

Table3. Correlations for Attitudinal Determinants of Management of Educational Resources and Students' Performance

\begin{tabular}{|c|c|c|c|}
\hline \multicolumn{4}{|c|}{ Correlation } \\
\hline & & $\begin{array}{l}\text { 1.Attitudinal Determinants of } \\
\text { Educational Resources Management }\end{array}$ & 2.Students' Performance \\
\hline \multirow{3}{*}{$\begin{array}{l}\text { 1.Attitudinal } \\
\text { Determinants of } \\
\text { Educational } \\
\text { Resources } \\
\text { Management }\end{array}$} & Pearson Correlation & 1 & $.081^{*}$ \\
\hline & Sig. (2-tailed) & & .023 \\
\hline & $\mathrm{N}$ & 318 & 318 \\
\hline \multirow{3}{*}{$\begin{array}{l}\text { 2.Students' } \\
\text { Performance }\end{array}$} & Pearson Correlation & $.081^{*}$ & 1 \\
\hline & Sig. (2-tailed) & .023 & \\
\hline & $\mathrm{N}$ & 318 & 318 \\
\hline
\end{tabular}

\footnotetext{
*. Correlation is significant at the 0.05 level (2-tailed).
}

Data from table 3 illustrates that there was a positive correlation between attitudinal determinants of educational resources management and students' performance $(\mathrm{r}=0.081, \mathrm{n}=318$, and $\mathrm{p}=0.023)$. Since the $\mathrm{p}$ value is 0.023 at two tailed level of significance, this value is less than the alpha level of $0.05(\alpha<.05)$ and it confirms that the relationship is statistically significant. The null hypothesis was therefore rejected. Therefore in Bungoma County, the attitudinal determinants seem to interfere with effective management of educational resources thereby having a significantly negative impact on students' performance in KCSE exams.

The present study established that some teachers in Bungoma County perceived teaching using instructional resources as time consuming. Since their workload was too much for them, getting time to prepare the resources was not easy. An interview conducted with head teachers confirmed this. In contrary, Begi (2007) and Kadzera (2006) articulated the fact that innovative teachers would always spend time to prepare and use instructional media in their instruction while those with negative 
attitude towards instructional media might not make any effort to prepare and use the instructional media during instruction. Zhao and Cziko (2001) observed that the Pedagogical beliefs of teachers and their teaching practices are factors that influence their uses of technology therefore they should be worked on for better results. This view is supported by Slouti and Barton (2007) whose findings indicated that technology can motivate students in their learning by bringing variety of media into the lessons and at the same time sustaining teachers' own interest in teaching.

Results from the present study indicate that most teachers in Bungoma County improvised alternative educational resources whenever they realized that they could not afford to buy particular educational resources. These results concur with those of Mwololo (2010) who observes that teachers who lack inventiveness, initiative and enthusiasm would find it imperative to teach using the most common media at their disposal; that is, chalk and chalkboard to the disadvantage of students' performance. He stressed the importance of improvising educational resources especially when the school could not afford to purchase one. The use of local resources is usually linked to improvisation where the teachers devise a substitute when the original material is not accessible. With similar views, Kadzera (2006) gives an example of a globe made from clay and articulated by a bamboo, which can be used to demonstrate rotation of the earth. He says improvisation here emphasizes the ability to make the item look like and function in the same way as the original material. It helps students to have a true picture of the situation; therefore, teachers need creativity and skills to help them use available materials to produce instructional media. Teachers need creativity and skills to help them use available materials to produce instructional media.

Results from the present study also indicate that some teachers in Bungoma County were afraid of using certain educational resources such as electronics and even realia whether harmful or harmless during teaching. Their perceptions come out clearly that they fear being close to them, touching and even using them to demonstrate an item. These results concur with those of Cox et al. (1999) who observed that some teachers do not use ICT in their instructional activities because they are computerfearful. Some teachers are fearful because of factors such as having little or no control over the activity, thinking of damage that might occur in using computers and feeling of low self-esteem. Some of them are fearful because they regard ICT and specifically computer as something that is likely to replace their role in school. As a matter of fact, some teachers also think that technology is beyond their abilities, having to cope with unfriendly jargon, and the likelihood of the technology going wrong.

\section{CONClusions}

From the findings it is also concluded that the attitude of teachers and students towards management and utilization of educational resources has influence on performance of students in KCSE exams. It was recommended that schools should provide teachers with friendly educational resources so that they will be able to use them with ease. Similarly, schools should involve teachers in drafting the policies and regulations on management of educational resources for them to implement them without resistance.

\section{REFERENCES}

[1] Abayomi \& Olukayode. (2006). Effects of Cooperative and Competitive learning strategies on students performance in Mathematics. The Nigerian Journal of Guidance and Counseling, 11(1):60-69, Ilorin Nigeria.

[2] Adepoju (2007) Teachers' Attitude toward School Library Services in Selected Secondary Schools in Ibadan, Oyo State. Unpublished Thesis

Akinsolu A.O (2003). Provision and management of facilities for primary education in Nigeria. Paper presented at the conference of Nigeria Association of Educational Administration and planning (NAEAP). University of Ibadan. Oct 29 th -31 .

[3] Allwright, R.L. (2000) Autonomy in language learning pedagogy. CRILE Working Paper.Centre for Research in Education, University of Lancaster

[4] Ayeni, M.F. (2005). The Role of Vocational and Technical Education in National Development. Journal of Research in Vocational and Education,.2 (1) : 111-117, Ikere-Ekiti

[5] Babette M \& Reitzes T. (2011) Education Development Center, Inc. (EDC). IntegratingTechnology with Student-Centered Learning. Quincy, MA: Nellie Mae Education Foundation. 
[6] Bausch, M. E., \& Ault, M. J. (2008). Assistive technology implementation plan: A tool for improving outcomes. Teaching Exceptional Children, 41(1), 6-14.

[7] Becker, H. J. (2007, April). How Are Teachers Using Computers in Instruction? Paper presented at the Annual Meeting of the American Educational Research Association, Seattle.

[8] Begi, N. (2007). A comparative study of preschool and lower primary school teachers, computer technology usage in teaching in Nairobi Province Kenya. VDM Verlag, Dr.Muller.

[9] Cohen, D., \& Hill, H. (2002). Instruction Policy and Classroom Performance: The Mathematics

[10] Cohen, D.K: Raudenbush, S.W: \& Ball, D.B: (2003): Resources Instruction and Research. Educationa Evaluation and Policy Analysis. 25.119-142

[11] Cox MJ, Preston C and Cox K (1999). What Motivates Teachers to Use ICT? Presented at the British Educational Research Association Annual Conference, University of Sussex at Brighton, September 2-5

[12] Dale, E. (1967). Audio-visual Methods in Teaching, the Dryden Press, New York.

[13] Kadzera, C. M., (2006). Use of instructional technologies in teacher training colleges, Malawi.(PHD Dissertation) in Virginia Polytechnic Institute and State University, Blacksburg,Virginia

[14] Karim, N., and Heckman, R., 2005, "Group communication media choice and the use of ICT to support learning: a case study”, Campus-Wide Information Systems, 22(1), ABI/INFORM Global, (28-42).

[15] Maddin E (1997). The real learning begins back in the classroom: on-the-job training and support for teachers using technology. Education technology. September- October, 56-59

[16] Mugure, S.N. (2012) "Impact of Resource Utilization In Education As Perceived By Teachers in Secondary Schools in Mathioya District, Muranga County, Kenya" Unpublished Thesis. Nairobi University

[17] Mwololo, N. J. (2011). Pre-school teachers' knowledge and attitude towards use of visual media in instruction in Kibwezi district, Kenya. Unpublished Masters thesis, Kenyatta University, Kenya

[18] Oni, J.O: (1995): Educational Resources: An Introduction. Abeokuta: Gbemi Sodipo press Ltd, in Akinsolu A.O (Eds). Resource Utilization and Internal Efficiency in Nigerian Secondary Schools: Implications for Socio Problems of Education. Paper presented at the conference of National Institute of Educational Administration and planning (NIEPA). Ondo, Nigeria

[19] Otu , J.A. (2011). Teachers in Ghana: Issues of Training, Remuneration andEffectiveness. Students: Setting the stage

[20] Rotumoi, J. \& Cheruto, L.K. (2014) Teachers' Attitudes towards the Use of Instructional Resources inTeaching of the Novel. Canadian Center of Science and Education. Vol. 4,(3). http://dx.doi.org/ 10.5539/ells.v4n3p58

[21] Slaouti D and Barton A (2007). Opportunities for practice and development: newly qualified teachers and the use of information and communication technologies in teaching foreign languages in English secondary school contexts. Journal of In-service Education, Vol. 33(4), 19.

[22] Smerdon, B., Cronen, S., Lanahan, L., Anderson, J., Iannotti, N., \& Angeles, J. (2000). Teachers' Tools for the $21^{\text {st }}$ Century: A Report on Teachers' Use of Technology. Washington DC: National Center for Educational Statistics.

[23] Yutchman, E: \& Seashore S: (1967): A System Resource Approach to Organizational Effectiveness, American Sociological Review, 32 891-903

[24] Zhao, Y., \& Cziko, G. A. (2001). Teacher Adoption of Technology: A Perceptual ControlTheory Perspective. Journal of Technology and Teacher Education, Vol.9 (1), 5-30.

[25] Zhao, Y., Pugh, K., Sheldon, S., \& Byers, J. (2002). Conditions for Classroom Technology Innovations. Teachers College Record.

Citation: Dr. Moses, Wesang'ula. "Attitudinal Determinants of Educational Resources Management for Enhancing Students' Performance in Secondary Schools in Bungoma County, Kenya." International Journal of Managerial Studies and Research (IJMSR), vol 5, no. 11, 2017, pp. 34-40. doi:http://dx.doi.org/10.20431/ 2349-0349.0511005.

Copyright: (C) 2017 Authors. This is an open-access article distributed under the terms of the Creative Commons Attribution License, which permits unrestricted use, distribution, and reproduction in any medium, provided the original author and source are credited. 